\title{
O fragmento como potência imaginária
}

Olívia de Melo Fonseca

UFF/IFF

\section{Resumo}

A partir da compreensão de que a escritura possibilita recriações de mais de um modo de se dizer e de se viver uma vida, as imagens que rondam o espaço-tempo dos textos de Roland Barthes serão ponderadas enquanto figuração de sujeitos, no plural, que tecem suas relações em trânsito afetivo e discursivo. Será possível apreender, então, que os fragmentos barthesianos resistem e sobrevivem ao entendimento histórico-linear do sujeito. Neles, as inquietações da escritura e da vida serão apreendidas como work in progress cujas linhas costuram um contra-discurso ${ }^{1}$ autobiográfico e romanesco.

Palavras-chave: Roland Barthes; fragmento; (des)figuração; romanesco.

\section{Resumen}

A partir de la comprensión de que la escritura posibilita recreaciones de más de un modo de enunciación y vivencia, las imágenes que rondan el espaciotiempo de los textos de Roland Barthes serán ponderadas como figuración de sujetos, en plural, que tejen sus relaciones en tránsito afectivo y discursivo. Será posible aprehender, por lo tanto, que los fragmentos barthesianos resisten o sobreviven al entendimiento linear de la historia del sujeto. En ellos, las inquietudes de la escritura y de la vida serán abordadas como work in progress, cuyas líneas tejen un contradiscurso, autobiográfico y novelesco.

Palabras clave: Roland Barthes; fragmento; (des)figuración; novelesco.
1. Para Michel Foucault ( $A$ ordem do discurso, 1998; $A$ arqueologia do saber, 2005), o contra-discurso é proferido por quem resiste e procura transgredir a ordem do discurso estabelecida por um sistema, seja este entendido aqui por uma ciência que regula o pacto autobiográfico. 
Um outro imaginário avançará então: o da escritura. E, para que esse imaginário possa desabrochar (pois tal é a intenção deste livro), sem nunca ser retido, garantido, justificado pela representação de um indivíduo civil, para que ele seja livre de seus próprios signos, jamais figurativos, o prosseguirá sem imagens, exceto as da mão que traça.

Roland Barthes

2. BARTHES, Roland. Roland Barthes por Roland Barthes, 2003, p. 121.

3. DE MAN, Paul.

"Autobiografia como des-figuração”, 2012

4. BLANCHOT, Maurice. O livro por vir, 2005, p. 321.
Tanto o autor Roland Barthes quanto a personagem de Roland Barthes por Roland Barthes tiveram tuberculose, padeceram com enxaquecas, mas também ambos afirmaram o prazer na realização de tarefas como pintar, escrever e preencher fichas com ideias para escritura de textos futuros. Por essa caracterização, em vez de escrevente, estereotipado, o leitor encontra-se diante da imagem textual de sujeitos que visam "a encenação de um imaginário" através da dispersão desta escritura por fragmentos ${ }^{2}$. Desta forma, o autor espalha suas possíveis características pelos retalhos desse e de outros livros seus, nos quais se cruzam linhas do repertório de leitura e de vida.

A escrita de si pode ser lida como representação silenciosa, tal qual a pintura do sujeito que tece sua imagem. Esta noção está em conformidade com o pensamento de Paul de Man sobre o texto autobiográfico em "Autobiografia como des-figuração" . Segundo ele, a autobiografia deve ser ponderada a partir dos conceitos de figuração e de desfiguração e, por conseguinte, deve ser lida como uma figura de leitura ou de entendimento. Tendo em vista tal embasamento, este trabalho busca pensar a imagem figurada pelo leitor do escritor que se encontra diante do impasse entre abdicar da vida fora da escritura e a obrigação de se trancar em sua oficina para escrever.

Enquanto o pensamento cartesiano afirma a relação imprescindível entre o sujeito e o mundo ou entre um eu e um interior, seria possível, por outro lado, pensar um sujeito ausente ao mundo ou fora de si? O espaço de produção literária é comumente pensado de forma segregada, fechada e sagrada. De acordo com Maurice Blanchot, esse espaço seria idealizado como o "Tibete imaginário"4 . Contudo, segundo este autor ainda, para escrever, é preciso entrar no templo, mas é importante buscar desconstruí-lo. Eis uma contradição vivida pelo escritor que se tranca em casa para escrever, embora tenha que permanecer fora de si para conduzir-se à escritura. A partir disso, torna-se interessante problematizar o distanciamento entre o pensamento reflexivo e o pensamento do fora. Se, de acordo com a primeira noção, o sujeito busca uma suposta verdade em si, por outro lado, de acordo com o pensamento do fora, o sujeito busca-a no outro, fora de si.

Em consonância com o pensamento blanchotiano, Foucault afirmou: "Na escrita, não se trata da manifestação ou da exaltação do gesto de escrever; não se trata da amarração de um 
sujeito em uma linguagem; trata-se da abertura de um espaço onde o sujeito que escreve não para de desaparecer" ${ }^{\prime 5}$. Diferente da linguagem reflexiva que tende a reduzir a escrita à interioridade, esse desaparecimento do sujeito está presente na escrita que tende à exterioridade do sujeito. Ela, assim, estaria em acordo com o conceito lacaniano de extimidade. Lacan $^{6}$ propôs este conceito para definir a "exterioridade íntima" e para repensar paradigmas filosóficos que foram construídos a partir de uma visão dicotômica, tais como a mediadora entre familiar e estrangeiro e o jogo de oposições entre interioridade e exterioridade. A extimidade localiza-se, ao mesmo tempo, no mais íntimo de cada sujeito e no mais exterior. Ela se delineia pelo medo que é familiar, pela recuperação do que foi perdido. Porém, em vez desta parte perdida vir complementar o que falta ao sujeito, ela arruína a sua realidade. Por isso, o êxtimo é, ao mesmo tempo, íntimo, estranho, desconhecido, ameaçador e angustiante.

No posfácio da Aula, "Lição de casa", Leyla Perrone-Moisés explica a escolha deste título, em vez da escolha da palavra lição, a qual também seria uma alternativa para a tradução da palavra francesa leçon. Em um primeiro momento, o leitor pode pensar que esta opção é indiferente, por estas palavras serem sinônimas: apresentação de um conteúdo feita por um professor a seus alunos. Segundo ela, em termos fonéticos, seria mais interessante a eleição de lição. Contudo, sua escolha foi pautada pelo cenário onde esta palavra iria circular. No Brasil, lição circunda o universo semântico do ensino primário e era essa extensão de sentido que a tradutora queria descarregar do título barthesiano. Além disso, Perrone-Moisés lembrou que, em espanhol, italiano e português arcaico, aula tem um sentido espacial, refere-se a um palácio, uma corte ou uma sala de honra. Ela sugeriu que fosse interessante atravessar o título por este sentido, pois a exposição de Barthes foi realizada em um espaço específico, de peso e poder na cultura francesa, o Collège de France. Porém, ainda de acordo com ela, tudo o que Barthes desejou foi deslocar este lugar estereotipado que iria ocupar. Para isso, ele escreveu toda a sua aula atravessada pelas ironias que lhe eram tão caras:

Barthes não propõe um objetivo, um lugar a salvo, uma verdade a ser atingida pela linguagem. Ele expõe e pratica uma diligência ao mesmo tempo obstinada e modesta: deslocar-se, praticar o indireto, abjurar, se necessário. Essa falta de objetivo prévio e de certezas reconfortantes o caracteriza como 'decepcionante', enquanto Mestre; ele se autodestitui de todo mestrado, recusa-se a ocupar o lugar do Pai e ousa propor como objetivo de seu ensino uma 'miragem' ou um 'fantasma'. E é aí que reside, talvez, a ironia maior dessa Aula que, sob o título pejado de conotações hierárquicas, institucionais e moralistas - Leçon - desmonta, em seu desenvolvimento, essas conotações. ${ }^{7}$
5. FOUCAULT, Michel.

"Prefácio à transgressão", 2009, p. 224.

6. LACAN, Jacques. O Seminário. Livro 7: A ética da psicanálise, 1997.

7. PERRONE-MOISÉS, Leyla.

"Lição de casa" (prefácio), 2007a, p. 63-64. 
8. Ibidem, p. 77.

9. BARTHES, Roland. Roland Barthes por Roland Barthes, 2003, p. 10.

10. Ibidem, p. 50.
Nessa desconstrução do espaço acadêmico e do discurso arrogante, Barthes desejou "criar, dentro do Colégio de França, uma área de jogo e de afeto" 8 . Um espaço, pois, para o fora onde se performa a literatura, a qual, na maioria das vezes, mantinha-se enclausurada na casa dele. Esse espaço marcado pelo trabalho burocrático e não-criativo faz com que o escritor, para criar, precise de todo o tempo livre que não lhe é disponível fora das férias. O narrador de Roland Barthes por Roland Barthes, muitas vezes, reclama desse tempo desperdiçado longe da escritura e o classifica em tédio, como nas seguintes legendas de fotografias para que posou em eventos de trabalho: "Desamparo: a conferência" e "Tédio: a mesa-redonda". Outra fotografia, de quando era menino, apresenta a mesma fisionomia de enfado, seguida do seguinte trecho que a legenda:

Em criança, eu me entediava frequentemente, e muito. Isso começou visivelmente muito cedo, e continuou durante toda a minha vida, por lufadas (cada vez mais raras, é verdade, graças ao trabalho e aos amigos), e sempre foi visível. É um tédio de pânico, chegando mesmo ao desamparo: como aqueles que experimento nos colóquios, conferências, noitadas estrangeiras, divertimentos de grupo: por toda a parte onde o tédio pode ser visto. Seria pois o tédio minha histeria?

O espaço de trabalho para o narrador está ligado ao prazer de realizar a obra tão sonhada: "Esse espaço é, em toda parte, o mesmo, pacientemente adaptado ao prazer de pintar, de escrever, de classificar $^{210}$. Da mitologia, ele recupera a metáfora da nave Argo para tentar explicar como se relaciona com as suas duas moradas de criação, uma em Paris e a outra no campo:

Imagem frequente: a da nave Argo (luminosa e branca), cujas peças os Argonautas substituíam pouco a pouco, de modo que acabaram por ter uma nave inteiramente nova, sem precisar-lhe mudar o nome nem forma. Essa nave Argo é muito útil: ela fornece a alegoria de um objeto eminentemente estrutural, criado não pelo gênio, a inspiração, a determinação, a evolução, mas por dois atos modestos (que não podem ser captados em nenhuma mística da criação): a substituição (uma peça expulsa a outra, como num paradigma) e a nominação (o nome não está de modo algum ligado à estabilidade das peças): à força de origem: Argo é um objeto sem outra causa a não ser seu nome, sem outra identidade a não ser sua forma.

Outra Argo: tenho dois espaços de trabalho, um em Paris, outro no campo. De um a outro, nenhum objeto comum, pois nada é mais transportado. Entretanto, esses lugares são idênticos. Por quê? Porque a disposição dos utensílios (papel, penas, carteiras, relógios, cinzeiros) é a mesma: é a estrutura do espaço que faz sua identidade. ${ }^{11}$ 
Para completar a narrativa mitológica em torno da nave Argo, sabe-se que, com o auxílio da deusa Atena, esta embarcação foi construída para que Jasão e os outros argonautas fossem em busca de aventuras. Jasão conseguiu vencer muitos obstáculos conduzindo-a e sendo conduzido por ela. Entretanto, como toda aventura possui o lado prazeroso e também o lado perigoso, na última delas, ele morre por causa de uma madeira de sua nau. Através da metáfora fornecida por Barthes, é possível ampliá-la por meio da imagem de que o espaço da escritura pode ser entendido tanto como o espaço da fruição quanto da angústia vivenciada pela irrealização da criação e por seu trabalho de correção infinita. Este medo pode ser traduzido pelas situações de tédio, tudo o que tirava o narrador de seu texto.

Em outro fragmento, "Horário", o narrador discorre sobre os seus afazeres diários. Se o título escolhido induz o leitor a pensar em tempo de trabalho, contraditoriamente, o texto inicia com a expressão: "Durante as férias". Este trecho serve para ilustrar que o tempo de trabalho da escritura é outro.

"Durante as férias, levanto-me às sete horas, desço, abro a casa, faço chá, pico o pão para os passarinhos que esperam no jardim, lavo-me, espano minha mesa de trabalho, esvazio seus cinzeiros, corto uma rosa, ouço o noticiário das sete e meia. Às oito horas, minha mãe desce por sua vez; como com ela dois ovos quentes, uma rodela de pão torrado e tomo café preto sem açúcar; às oito e um quarto, vou buscar o jornal Sud-Ouest na cidade; digo à Senhora C.: o tempo está bom, o tempo está feio, etc, e depois começo a trabalhar. Às nove e meia, passa o carteiro (o ar está carregado hoje, que lindo dia, etc.), e, um pouco mais tarde, em sua caminhonete cheia de pães, a filha da padeira (ela é estudada, não convém falar do tempo); às dez e meia em ponto, faço café preto e fumo meu primeiro charuto do dia. À uma hora, almoçamos, faço a sesta da uma e meia às duas e meia. Vem então o momento em que flutuo: nenhuma vontade de trabalhar; às vezes faço um pouco de pintura, ou vou buscar aspirina na farmácia, ou queimo papéis no fundo do jardim, ou fabrico uma carteira, um escaninho, uma caixa para fichas; chegam assim quatro horas e novamente trabalho; às cinco e um quarto, é o chá; por volta das sete horas, paro de trabalhar; rego o jardim (se o tempo está bom) e toco piano. Depois do jantar, televisão: se aquela noite ela está boba demais, volto à minha mesa, ouço música e faço fichas. Deito-me às dez horas e leio, um após outro, um pouco de dois livros: por um lado, uma obra de língua bem literária (as Confissões de Lamartine, o Diário de Goncourt, etc.), por outro lado um romance policial (de preferência antigo), ou um romance inglês (fora de moda), ou Zola."

- Tudo isso não tem nenhum interesse. Ainda mais: não só você se marca como pertencente a uma classe, mas ainda você faz dessa marca uma confidência literária, cuja futilidade não tem mais aceitação: você se constitui 
13. AUTHIER-REVUZ, Jacqueline. "Heterogeneidade(s) enunciativa(s)". Cadernos de Estudos Linguísticos, 1990.
Interessante notar como foi estruturado o fragmento acima: o primeiro parágrafo escrito em discurso direto, tal qual marcam as aspas e o discurso em primeira pessoa do singular, seguido de outro, também em discurso direto, sem aspas, mas apontado pelo uso do travessão. Por que a escolha pelo uso das aspas no primeiro parágrafo? Abrem-se aspas para citar integralmente algum depoimento dado pelo outro extratextual que é revelado ao leitor, na maioria das vezes, após o fechamento delas. Ao usar de sua voz para dar voz ao outro, o sujeito torna-se porta-voz deste.

De acordo com Jacqueline Authier-Revuz em "Heterogeneidade(s) enunciativa(s)"13, as aspas podem ser definidas como uma das formas de "heterogeneidade mostrada" por inscreverem o outro na progressão do discurso. Essa autora distingue essa forma marcada da forma de "heterogeneidade não marcada", como é o caso do discurso indireto livre e da ironia, por exemplo. Para pensá-la, deve-se levar em conta, por conseguinte, duas questões: a alteridade; e o lugar na fala do eu, em suas relações de coerência e coesão, para a fala de outrem.

No fragmento barthesiano em análise, esse outro permanece indeterminado. Entretanto, o discurso proferido por seu narrador parece ter sido proferido pelo próprio autor Roland Barthes. Por que, então, este fez uso de aspas para um depoimento que, implicitamente, parece ser seu e que não fora retirado de outro contexto? Em um texto autobiográfico, por que o uso de aspas para expressar a fala de seu autor? Uma hipótese se esboça: nesse texto ao revés, as vozes desse narrador não se enclausuram na voz monológica de seu autor.

Pode-se depreender, a partir disso, que todas as confissões nessa obra são tecidas e desfiadas, o tempo todo, para o leitor, o qual já fora avisado de que se encontra diante de uma personagem de romance e o qual deve saber que:

O lapso não é a única forma de emergência tangível do Outro no discurso; as formas marcadas da heterogeneidade mostrada também o são, mas sob as formas desviantes do domínio do dito; em conflito solidário com a heterogeneidade constitutiva estas formas são em relação àquelas ao mesmo tempo um sintoma e uma defesa; justamente onde o lapso, emergência bruta, produz "buraco" no discurso, elas dão a imagem de um espaço, de uma sutura sublinhada pela costura que o anula.

Ao conjunto de fissuras, junções que funcionam como costuras escondidas sob a unidade aparente de um discurso e que a análise - análise do discurso, descrição dos textos literários e poéticos, psicanálise - pode em parte evidenciar como pistas do interdiscurso ou do jogo do significante, as 
formas marcadas da heterogeneidade mostrada opõem a retórica da falha mostrada, da "costura aparente". ${ }^{14}$

A esse respeito, Giorgio Agamben teoriza em "O autor como gesto". Morfologicamente, gesto pode ser definido como substantivo masculino e, dentre os seus significados, constam: movimento expressivo de ideias; aceno; trejeito; aspecto; aparência. Por sua vez, gestar é verbo e, dentre os seus significados, observa-se: dar a origem a; criar. Tendo como conhecidos os sentidos dicionarizados desta palavra, torna-se importante recorrer ao sentido atribuído a ele por Agamben: "Se chamarmos de gesto o que continua inexpresso em cada ato de expressão, poderíamos afirmar então que [...] o autor está presente no texto apenas em um gesto, que possibilita a expressão na mesma medida em que nela instala um vazio central" ${ }^{\text {"15. }}$.

De acordo com este teórico, o paradoxo da presença-ausência do autor no texto está ligado justamente ao fato de sua expressão apresentar-se como vazio ou como gesto. Contudo, o autor não pode sair da obra. Ele deve permanecer nela de modo ilegível e irrealizado, como uma "presença incongruente e estranha", pois é "o gesto do autor que garante a vida da obra unicamente através da presença irredutível de uma borda inexpressiva" ${ }^{16}$. Esse seria o fora sugerido por Blanchot ou o êxtimo pensado por Lacan: o lugar que ficou vazio no texto é o que torna possível a leitura, visto que o ter lugar "não está, pois, nem no texto nem no autor (ou no leitor): está no gesto no qual autor e leitor se põem em jogo no texto e, ao mesmo tempo, infinitamente fogem disso" ${ }^{\prime 17}$.

Entretanto, ao passo que permanece ausente, é o autor também que põe o limite até onde pode ir a interpretação do leitor: "Pois tão ilegítima quanto a tentativa de construir a personalidade do autor através da obra é a de tornar seu gesto a chave secreta da leitura"18. O leitor sabe, então e apenas, que, nesse gesto, há uma figuração de subjetividade. Além dessa informação, para Agamben, o leitor encontrará psicologia e, nesta, não há "algo parecido com um sujeito ético, com uma forma de vida" $"$.

Essa hipótese está em consonância ainda com Evando Nascimento que afirmou, em "Retrato do autor como leitor", que a biobibliografia deve interessar mais ao leitor do que a biografia:

O autor é um dispositivo tanto pessoal quanto impessoal, no limite do anonimato. É-se autor em princípio em primeira pessoa, "Eu escrevo", mas em seguida é preciso que se transforme em diversas outras pessoas, tanto discursivas quanto empíricas: ele/eles, você/tu, vocês, nós e até o antigo vós. Um autor plenamente autoidentificado é natimorto, pois incapaz de assumir diversas máscaras sem as quais não há autoria: vozes narrativas, personagens, sujeitos
14. Ibidem, p. 34 .

15. AGAMBEN, Giorgio. "O autor como gesto”, 2007, p. 53.

16. Ibidem, p. 61.

17. Ibidem, p. 61-62.

18. Ibidem, p. 61-62.

19. Ibidem, p. 63. 
20. Disponível em: http:// www.evandonascimento.net. br/ensaios/retrato_do_autor_ como_leitor.pdf.

\section{AUTHIER-REVUZ,} Jacqueline. "Heterogeneidade(s) enunciativa(s)", 1990, p. 29. poéticos, vozes dramáticas, dramatis personae, personas ensaísticas, biográficas, sociais, em suma, máscaras de toda ordem. Parafraseando Nietzsche, eu diria que o autor é uma composição de grande mascarada. Sem esses registros heterográficos (e heteronômicos, segundo Fernando Pessoa), francamente miméticos, cai-se no expressionismo de um eu que apenas sabe dizer eu, nunca ele/ela, você, nós, vocês. ${ }^{20}$

Por esse pensamento, que inclusive é tido como uma das teses barthesianas desde o famoso texto "A morte do autor", a imagem do autor pulveriza-se no texto de vozes indeterminadas, apesar de parecerem ou terem o desejo de parecer apenas implícitas ao leitor. Assim, de acordo com Authier-Revuz:

Em ruptura com o EU, fundamento da subjetividade clássica concebida como o interior diante da exterioridade do mundo, o fundamento do sujeito é aqui deslocado, desalojado, 'em um lugar múltiplo, fundamentalmente heterônimo, em que a exterioridade está no interior do sujeito'. Nessa afirmação de que, constitutivamente, no sujeito e no discurso está o Outro, reencontram-se as concepções do discurso, da ideologia, e do inconsciente, que as teorias da enunciação não podem, sem riscos para a linguística, esquecer. $^{21}$

De volta ao primeiro parágrafo do fragmento barthesiano em análise, nota-se a repetição do dia-a-dia do narrador, durante o período de férias. De forma irônica, o narrador vai contando o que realiza acerca de cada quinze minutos do dia como se isso fosse de extrema relevância e como se ele, enquanto escritor, fosse dar conta, além de viver, de narrar o diário minunciosamente, conforme pode ser demonstrado pela expressão "em ponto", em “às dez e meia em ponto”. Esta expressão induz o leitor a pensar que comprovou a exatidão do tempo, a pontualidade vivida pelo autor desejado. Além do discurso direto aberto com o leitor, há passagens em que a fala da personagem é dirigida a certos conhecidos e, para se diferenciar da fala dirigida ao primeiro, aparece em itálico. Entretanto, no discurso remetido à Senhora C. ou ao carteiro, a função de linguagem predominante é a fática. Seu papel é apenas encurtar a distância entre mundos tão diferentes e estereotipados, o do intelectual, o da dona da banca e o do carteiro. Nada como conversar sobre o tempo para preencher a lacuna cultural que, pelo senso comum, já se espera tão grande, tal é assinalado por meio da explicação da filha da padeira: "(ela é estudada, não convém falar do tempo)". Além do encurtamento da diferença cultural, mesmo que caricata, é possível pensar que, metalinguisticamente, com o uso da função fática da linguagem, o narrador também quer cobrir os buracos de seu texto. Afinal, o que ele tem tanto a dizer, de seu dia fora do texto, a seu leitor? 
O segundo parágrafo se abre ao diálogo, tendo em vista que é dirigido a um você. A resposta esperada para a pergunta lançada logo acima começa a ser escrita. O que parece é que toda vez que a narrativa tende a ser guiada pela escrita banal diária, como um monólogo, outra voz aparece no texto para censurar a escrita esperada, estereotipada. Este tipo de uso da língua é o que Barthes rejeita em sua Aula:

Em nossa língua francesa, vejo-me adstrito a colocar-me primeiramente como sujeito, antes de enunciar a ação que, desde então, será apenas meu atributo: o que faço não é mais do que a consequência e a consecução do que sou; da mesma maneira, sou obrigado a escolher sempre entre masculino e feminino, o neutro e o complexo me são proibidos; do mesmo modo, ainda, sou obrigado a marcar minha relação com o outro recorrendo quer ao $t u$, quer ao vous; o suspense afetivo ou social me é recusado. Assim, por sua própria estrutura, a língua implica uma relação fatal de alienação. Falar, e com maior razão discorrer, não é comunicar, como se repete com demasiada frequência, é sujeitar. ${ }^{22}$

Quanto aos sujeitos discursivos presentes em seus textos de cunho autobiográfico, especialmente Roland Barthes por Roland Barthes, é possível identificar as pessoas gramaticais tu/ você, ele e também as iniciais R.B., aqueles que são narrados por outro, e o eu performativo, aquele que possui a autoridade para narrar a própria história. Todavia, de acordo com Benveniste:

A que, então, se refere o ex? A algo muito singular, que é exclusivamente linguístico: en se refere ao ato de discurso individual no qual é pronunciado, e lhe designa o locutor. É um termo que não pode ser identificado a não ser dentro do que, noutro passo, chamamos uma instância de discurso, e que só tem referência atual. A realidade à qual ele remete é a realidade do discurso. É na instância de discurso na qual $e u$ designa o locutor que este se enuncia como 'sujeito'. ${ }^{23}$

Se, por um lado, o pronome $e$ u particulariza a enunciação, por outro, ele é único para expressar qualquer sujeito que deseja assumir o lugar de locutor, pois a noção de pessoa está presente nos pronomes en e tu e ausente em ele, pronome da não-pessoa. Deste modo, a linguagem é, ao mesmo tempo, particular e compartilhada. Este aspecto é notado por Éric Marty, em "Roland Barthes: o ofício de escrever", no qual observa que a construção de Fragmentos de um discurso amoroso é realizada pela simulação do discurso do vivido empírico ${ }^{24}$. O locutor não pode ser entendido como o próprio Barthes, sujeito determinado "pela estrutura espaço-temporal do mundo, tendo uma idade, uma identidade, sexo, nome, biografia, pais, endereço etc.", que resolve se confidenciar a seu leitor, mas como uma "consciência simulada" 25 .
22. BARTHES, Roland. Aula, 2007a, p. 12-13.

23. BENVENISTE, Émile. Problemas de linguistica geral I, 2005, p. 288.

24. Segundo Éric Marty (Roland Barthes: o ofício de escrever, 2009, p. 285): “A simulação seria a boa cópia (a boa imitação), pois, na simulação, o imitador não lhe é estrangeiro. A simulação obriga o ator (o simulado) a uma espécie de mutação existencial em que fica impelido a obedecer a um papel".

25. MARTY, Éric. Roland Barthes: o oficio de escrever, 2009, p. 281. 
O eu é imaginário, flexível, não anuncia uma pessoa particular.

O eu está em polaridade com o $t u$ :

Pois se digo "tu" ao outro é porque admito que, por sua vez, esse "tu" se tornará um "eu" e que eu serei então seu "tu": há um entrelaçamento, um quiasma de pessoas. Para Benveniste é justamente essa polaridade dialética do "eu" e do "tu" que constitui a estrutura da subjetividade humana. Essa subjetividade concilia, portanto o singular (é o sujeito que fala) e o universal (para falar, toma de empréstimo uma forma única e que vale por todas) e articula o "eu" e o Outro, já que ao falar passamos sem cessar entre o "eu" e 26. Ibidem, p. 283. o "tu", numa pura reciprocidade. ${ }^{26}$

Entretanto, segundo Marty, o eu do texto barthesiano não pode se identificar com o $e u$ universal, pois "não é um 'universo-singular' no sentido banal e burguês". A este sujeito, é consentido dizer $e$ e também $t u$. Porém, não lhe é permitida a permuta do $e u$ e do $t u$, pois não poderá ser $t u$ para o outro que nunca fala: "Podemos, então, notar a simetria que existe entre esse 'eu' e o 'eu' lírico, cuja palavra tem como único campo de referência ele próprio e cujo interminável proferimento não chega nunca a uma resposta".

Estes "gestos de deslocamento" discursivos são uma lição que sempre retorna no texto barthesiano, como indicou Perrone-Moisés em seu posfácio para a Aula:

A convicção de Barthes - expressa na Aula - é de que a língua deve ser combatida e desviada do interior, por gestos de deslocamento. Assim, Barthes desloca as palavras, desfocaliza significantes de significados, desnivela a enunciação, marginaliza o discurso institucional, submetendo o terreno linguístico a breves mas constantes sismos. E esses breves abalos fazem oscilar o sujeito pleno no discurso logocêntrico, colaborando para que um novo sujeito aflore na História, liberto do imaginário (discurso, ideologia) que, por enquanto, o lastreia e entrava. Esse é o alcance político (no

27. PERRONE-MOISÉS, Leyla. "Lição de casa" (prefácio), 2007a, p. 69.

28. MARTY, Éric. Roland Barthes: o oficio de escrever, 2009, p. 284.

29. BARTHES, Roland. Roland Barthes por Roland Barthes, 2003, p. 160.

30. MARTY, Éric. Roland Barthes: o oficio de escrever, 2009, p. 286.
É interessante lembrar ainda que o discurso tecido por Barthes encontra-se reduzido ao en que anuncia e também ao que é anunciado, um texto fragmentado e recortado: "acesso a sombras de frases, a frases atrofiadas, a frases-palavras" 28 . Conforme observado, este texto é movido pelas suspensões do funcionamento convencional da estrutura pronominal e da narratividade. Estes fragmentos costurados, espécie de patchwork ${ }^{29}$, implicam um gozo imediato. Neles, há "uma descontinuidade no eu que fala, como se várias vozes viessem a lhe sobrepor e produzissem um efeito de polifonia. Neles, o "eu" se apresenta, portanto, como um "eu" segundo, como um outro timbre que, em surdina (a surdina dos parênteses), viria a sustentar a voz central" ${ }^{30}$. 
É preciso prestar atenção no que é dito entre parênteses por Barthes, pois conforme declarou Derrida: "O parêntese não encerra algo incidental ou uma ideia secundária, como acontece com frequência; não é o dito em voz baixa sob o ângulo de pudor" ${ }^{\prime 31}$. É preciso prestar atenção também nos fragmentos barthesianos e nos neologismos criados por ele para tentar defini-los. Defensor do exercício de escritura que se volta para o estilhaço em vez de voltar-se para um elemento totalizador, em seu trabalho com a escrita de si, Roland Barthes desterritorializa o território discursivo autobiográfico em voga. Ao optar por um discurso desterritorializado, tende a fazer uso de uma linguagem revolucionária e transgressiva e o faz pelas bordas do texto. Por isso, o seu interesse pelo fragmento e por isso também criou, ao longo de sua obra, diversos conceitos para tentar pensar esta escritura do esboço, tais quais os já referenciados neste trabalho, como também: intermezzo $0^{32}$, figura, traco $0^{33}$, inciden$t^{34}$, haicai, narrem ${ }^{35}$, punctum, biografema.

O fragmento ganha importância ainda na leitura feita por Barthes de fotografias. Em A câmara clara, ele nomeia de punctum o que irrompe na fotografia, apunhalando e ferindo o espectador profundamente. Esta acepção apresenta-se em discordância da noção de studium, que seria definida como o interesse geral ou o "afeto médio" que a fotografia desperta no espectador. O studium ocorre nas fotos encenadas, uma vez que o punctum tem lugar nas fotos que são tiradas por acaso. As primeiras são chamadas de fotografias unárias, visto que são a unidade da representação e, por isso, não desdobram a realidade. As fotografias de reportagem e as pornográficas são dois exemplos dados por Barthes ao leitor: as fotos de reportagem "são recebidas, é tudo. Folheio-as, mas não as rememoro; nelas, nunca um pormenor (em tal canto) vem interromper a minha leitura", já a fotografia pornográfica é "como uma vitrine que, iluminada, só mostrasse uma única joia, ela é inteiramente constituída pela apresentação de uma única coisa, o sexo: nunca há um segundo objetivo, intempestivo, que venha semiesconder, adiar ou distrair". De tal forma, é possível afirmar que o punctum, a afetividade provocada pela fotografia, passa a olhar e a ferir o espectador no momento em que deixa de ver o studium, a procura pela interpretação e pelo interesse comum e geral da fotografia.

Em comparação com estas duas últimas definições, Barthes criou mais outras duas para problematizar as práticas de escrita e de leitura biográficas e fragmentárias. Em detrimento à thanatografia, que seria compreendida como o uso do biográfico que sufoca a vida, Barthes elege o biografema, destaque para o detalhe de uma vida como potência criadora. Tal conceito aparece em diversos momentos de sua obra, mas é destacado em Sade, Fourier, Loiola. Este estilo de escritura possibilitaria recriações de mais de um modo de se dizer e de se viver uma vida.
31. DERRIDA, Jacques. "As mortes de Roland Barthes". Revista Brasileira de Sociologia da Emoşão, 2008, p. 277.

32. Barthes buscou pensar a sua prática de escritura em relação com a música de Schumann e a sua estética do fragmento: "Ele [Schumann] chamava o fragmento de intermezzo; ele multiplicou em suas obras os intermezzi: tudo o que produzia era finalmente intercalado". BARTHES, Roland. Roland Barthes por Roland Barthes, 2003, p. 110.

33. Referência a seus Fragmentos de um discurso amoroso (2007, p. 18), os quais foram por ele nomeados de figuras: "Podemos chamar esses cacos de discurso de figuras". Por sua vez, o desdobramento das figuras é aquilo que, neste mesmo texto, Barthes chamará de traço.

34. Incidentes é o título de um de seus livros, o qual pode ser divido em duas partes maiores: a primeira é uma espécie de diário de viagem, quando esteve no Marrocos entre 1968 e 1969; a segunda também contempla o exercício diarístico realizado durante a sua travessia pelas "Noites de Paris" entre 24 de agosto e 17 de setembro de 1979. O que o leitor encontra nesta leitura são impressões fragmentadas desta viagem. Daí, o título proposto para o livro ser Incidentes. Vale mencionar que em Roland Barthes por Roland Barthes (2003), o narrador alude a este texto em dois fragmentos de títulos sugestivos, "Projetos de livro" (p. 166-167) e "Que quer dizer isto?” (p. 167-168), respectivamente: "Incidentes (minitextos, recados, haicais, anotações, jogos de sentido, tudo o que cai, como uma folha), etc."; “(Aqui mesmo, exceto nas Anamneses, cujo preço é exatamente, não se suporta 
nada que deixe de significar, não se ousa deixar o fato num estado de in-significância; é o movimento da fábula que tira de qualquer fragmento de real uma lição, um sentido. Um livro inverso poderia ser concebido: que contasse mil 'incidentes', proibindo-se de jamais arrancarlhes uma linha sequer de sentido, seria precisamente um livro de haicais)".

35. Para Barthes, a menor forma de narrativa possível, devido a sua capacidade sintética, é o haicai que, por sua vez, foi por ele chamado de narrema, ambos ganharam destaque em $A$ preparação do romance I (2005).

36. BARTHES, Roland. Roland Barthes por Roland Barthes, 2003, p. 11.

37. Ibidem, p. 55 .
Diferentemente da prática autobiográfica tradicional, a thanatografia, que tinha como objetivo a apreensão totalizante de uma vida pela escrita, a prática biografemática volta-se para o detalhe, o ínfimo, o impreciso e o insignificante de uma vida.

Toda essa campanha pela escritura em estilhaços pode ser lida por outra ótica, tendo em vista o trecho em que o narrador de Roland Barthes por Roland Barthes expôs o medo que teve da crítica, a qual dizia que seu texto não fluía pelo fato de ser tecido por fragmentos entrecortados. Configurando essa crítica como uma impossibilidade de escritura para ele, um de seus fragmentos foi intitulado de "O medo da linguagem":

Escrevendo tal texto, ele experimenta um sentimento culposo do jargão, como se ele não pudesse sair de um discurso demente por força de ser particular: e se em toda a sua vida, em suma, ele se tivesse enganado de linguagem? Esse pânico toma conta dele de modo mais agudo aqui (em U.) porque, não saindo à noite, ele vê muita televisão: o tempo todo é-lhe então representada (admoestada) uma linguagem corrente, da qual ele está separado; essa linguagem lhe interessa, mas isso não é recíproco: ao público da televisão, a linguagem dele pareceria inteiramente irreal (e, fora do gozo estético, toda linguagem irreal corre o risco de ser ridícula). Tal é a inflexão da energia de linguagem: num primeiro tempo, escutar a linguagem dos outros e tirar dessa distância uma segurança; e, num segundo tempo, duvidar desse recuo: ter medo daquilo que se diz (indissociável da maneira como se diz).

Acerca do que acaba de escrever, durante o dia, ele tem medos noturnos. A noite, fantasticamente, traz de volta todo o imaginário da escritura: a imagem do produto, a fofoca crítica (ou amistosa): é muito isto, muito aquilo, não é bastante... À noite, os adjetivos voltam, em massa. ${ }^{36}$

Em relação aos adjetivos mencionados neste trecho, vale lembrar que: "Ele considera que a perfeição de uma relação humana depende dessa vacância da imagem: abolir entre si, de um a um outro, os adjetivos; uma relação que se adjetiva está do lado da imagem, do lado da dominação, da morte" 37 . O narrador barthesiano não os suporta por tentarem descrever ou nomear uma imagem sua feita pelo outro, no caso, os críticos. A estes críticos ferrenhos da obra barthesiana, Leyla Perrone-Moisés recomenda a aprenderem com a sua Aula:

Grande parte das polêmicas criadas contra Barthes se detêm em questões de palavras, desde os ataques de Raymond Picard contra os neologismos da 'nouvelle critique' até as mais recentes discussões acerca da pertinência do adjetivo 'fascista' atribuído à 'língua'. Esses censores perecem não perceber que Barthes trabalha com a língua como um escritor e não como um dissertador. Como os poetas, ele explora, nas palavras, suas conotações, suas ambiguidades, 'a 
cintilação do sentido' mais do que o sentido. A palavra é para ele um objeto sensual, núcleo de onde pode expandir-se todo um movimento textual ou, inversamente, concentração ideal, lugar onde se condensa todo um pensamento. ${ }^{38}$

Já no papel de crítico, em "Literatura Descontínuo", presente em Crítica e Verdade, Barthes afirmou que, tradicionalmente, a quebra da linearidade e da progressão da história só é permitida à poesia: "afora a poesia, nenhum atentado ao Livro pode ser tolerado" 39 . Entretanto, ao tecer uma crítica em relação ao livro Mobile, de Michel Butor, ele reavaliou:

\begin{abstract}
Se portanto Mobile peca com relação à ideia consagrada (isto é, sagrada) do Livro, não é por negligência, é em nome de uma outra ideia de um outro Livro. Qual? Antes de o ver, é preciso tirar da querela de Mobile dois ensinamentos concernentes à natureza tradicional do livro. ${ }^{40}$
\end{abstract}

De acordo com Barthes, em Mobile, há dois questionamentos em torno da ideia tradicional de Livro. Um deles é que "o Livro-Objeto confunde-se materialmente com o Livro-Ideia, a técnica de impressão com a instituição literária". Em virtude disso, Mobile provoca "contra a regularidade material da obra" 41 e, por isso, visa à própria ideia da literatura. O segundo questionamento está na ideia de Livro enquanto relação entre narrativa e continuidade e é sobre essa consonância que Barthes quer repensar: “dividir é dissecar, é destruir, é profanar o 'mistério' do livro, isto é, seu contínuo" ${ }^{42}$.

Em "Elogio da profanação"43, Giorgio Agamben define a profanação como a restituição do que seria sagrado ao uso comum dos homens. Os campos do sagrado e do jogo possuem uma interseção. Agamben lembra que a maioria dos jogos, como os jogos com bola, os jogos de azares, o jogo de xadrez, resultaram de ritos sagrados. Paradoxalmente, o jogo retira o sujeito do sagrado. Essa profanação pode ser compreendida como a recomendada por Barthes, o qual recupera os significados possíveis para a palavra jouer na língua francesa: brincar, arriscar, performar/encenar e também executar uma música. Se profanar é retirar algo da esfera sagrada e humanizá-lo, o jogar se aproxima desta palavra semanticamente, pois quem se lança ao jogo está disposto a se arriscar, a sair de seu lugar de conforto para ocupar um lugar provisório enquanto encena o outro.

A partir deste entendimento da palavra profanação, é possível pensar que Mobile profana a forma contínua e sagrada da narrativa, pois se aventura neste jogo de deslocamento e de desmecanicização da estrutura. Nesse sentido, Mobile está mais próximo do sentido dado por Barthes a texto do que a obra, visto que aquele coloca esta em jogo, em prática, em produção. Essa profanação articulada pelo texto de Butor é justamente o que
38. PERRONE-MOISÉS, Leyla. "Lição de casa" (prefácio), 2007a, p. 73-74.

39. BARTHES, Roland. "Literatura Descontínuo", 2007c, p. 112.

40. Ibidem, p. 113.

41. Ibidem, p. 113.

42. Ibidem, p. 114.

43. AGAMBEN, Giorgio.

"Elogio da profanação", 2007. 
44. BARTHES, Roland.

"Literatura Descontínuo", 2007c, p. 114.

45. Ibidem, p. 121.

46. PINO, Claudia Amigo.

Roland Barthes: a aventura do romance, 2015, p. 13.

47. SOUZA, Eneida Maria de. "Prefácio", 2015, p. 07.

48. BARTHES, Roland. "O escritor como fantasma”, 2003, p. 91-92.
Barthes elogia e o que a crítica tradicional da época entendia como infração. O seu interesse neste texto se justifica pela escritura descontínua e pelos fragmentos narrativos que enaltecem o detalhe: "o detalhe não é um material fundamental, é uma moeda inessencial: trocam-se as grandes ideias em 'detalhes' sem poder imaginar por um instante sequer que as grandes ideias possam nascer do simples arranjo dos "detalhes""44. Assim, em oposição à critica tradicional que desdenhou Mobile ao caracterizá-lo como "pensamento em migalhas" 45 , Barthes fez-lhe elogios por privilegiar o detalhe e a forma descontínua.

As últimas obras de Barthes exploram ainda mais o exercício autobiográfico a partir de fragmentos que, por serem datados muitas vezes, aproximam-se do gênero diarístico. Para tecer o livro Roland Barthes: a aventura do romance, Claudia Amigo Pino pesquisou as fichas e os manuscritos deixados por ele como o germe de seu Vita Nova. Dessa investigação, chegou a uma primeira conclusão: "não só os diários faziam parte do romance: havia ainda centenas de fichas sobre o projeto, mas ninguém podia me dizer onde elas se encontravam, já que elas não faziam parte do inventário do acervo" "46. Assim, Pino iniciou seu percurso por caminhos idealizados pelo escritor para a escritura de seu romance e que iriam conduzir à expansão do legado desta obra. Conforme anunciado por Eneida Maria de Souza em prefácio escrito ao livro, o trabalho desta autora foi de arquivamento, tal qual o sentido procurado por Jacques Derrida para esta palavra:

Penetrar nos silêncios e rasuras dos papéis de escritores é
recuperar muito do seu empenho em deixar uma obra ina-
cabada e, portanto, suscetível de múltiplas interpretações e
de futuras entradas. É desta crítica em processo e em busca
de gêneses textuais que reside a significativa contribuição
deste trabalho. ${ }^{47}$

Pensando na recepção destes textos fragmentados como convém ao estilo barthesiano, é possível compreender porque muitos o viam como a figura de um fantasma. Conforme ele mesmo teorizou, o escritor que pratica a escrita diarística não realiza a obra e, por isso, ronda como uma imagem fantasmática no imaginário do leitor: "Aquilo que o fantasma impõe é o escritor tal como podemos vê-lo em seu diário íntimo, é o escritor menos sua obra: forma suprema do sagrado: a marca e o vazio"48. Por conseguinte, em seus papéis avulsos, Barthes sobrevive de modo espectral como leitor e autor por fazer-se no presente, sem pertencer a um passado ou a um futuro:

Heterogêneo, intempestivo e deslocado em relação ao presente, o tempo do espectro, como da sobrevivência, legitima a existência da leitura como gesto em contínua 
transformação. Os rastros desses escritores no arquivo, a herança legada aos leitores e seguidores de sua obra se constituem como desafio à prática desconstrutora, no sentido de se levar em consideração que no processo de revitalização da escrita exige-se também o deslocamento de saberes instituídos. ${ }^{49}$

A obra, em aberto, não morreu com seu autor. Os inéditos estão sendo revirados e publicados após a sua morte. A partir da leitura do texto de Pino, Eneida Maria, portanto, propõe que o romance barthesiano existe fora da lógica de uma tradição romanesca ou de uma crítica literária tradicional que o definem como texto inacabado. Em outra perspectiva, ele sobrevive, à luz do pensamento de Deleuze e Guattari, como um quase-romance ou como um romance em devir. "Um quase-romance, assumido por um devir-escritor" ${ }^{50}$. Por não ser adepto a um formato, ele sobrevive como álbum, tal como este conceito foi cunhado pelo próprio Barthes em sua "Deliberação" "51. Nesta, o autor propõe a compreensão da palavra álbum tendo em vista a leitura feita dela por Mallarmé, de que seria o conjunto de folhas soltas, permutáveis e suprimíveis infinitamente e que se oporia à noção de acabamento que ronda a palavra livro/obra.

Destarte, a fim de pensar a figura mítica que é o escritor, cabe a leitura do texto "O escritor de férias", presente em $\mathrm{Mi}$ tologias. Mesmo de férias, o autor está a trabalho, anotando algo em seu diário, que aproveitará como matéria prima assim que chegar a um local propício, onde possa se lançar à escritura. Barthes, desta forma, tenta mostrar que até a imagem do escritor é produzida por uma leitura cultural. E, depois de sua morte, essa é a imagem fantasmática que passou a rondar o imaginário de seu leitor: um escritor francês que, após fazer suas anotações, não conseguiu chegar a tempo de adentrar pelo espaço romanesco. Em vez de um romance finalizado, o que Barthes deixou como legado foi o diário de sua preparação. Ou seria o contrário, a sua preparação enquanto diário?
49. SOUZA, Eneida Maria de.

"Prefácio", 2015, p. 08.

50. Ibidem, p. 9.

51. BARTHES, Roland.

"Deliberação", 2004a. 


\section{Referências}

AGAMBEN, Giorgio. Profanações. Tradução de Selvino José Assmann. São Paulo: Boitempo, 2007.

O que é o contemporâneo? e outros ensaios. Tradução de Vinícius Nicastro Honesko. Chapecó-SC: Argos, 2009.

AUTHIER-REVUZ, Jacqueline. "Heterogeneidade(s) enunciativa(s)". Cadernos de Estudos Linguísticos. No 19.

Campinas: jul/dez de 1990, p. 25-42. Disponível em: http:/ / revistas.iel.unicamp.br/index.php/cel/article/view/3012. Acesso em: 19/02/2016.

BARTHES, Roland. Roland Barthes por Roland Barthes. Tradução de Leyla Perrone-Moisés. São Paulo: Estação Liberdade, 2003.

. Incidentes. Tradução de Mário Laranjeira. São Paulo:

Martins Fontes, 2004.

. O rumor da língua. Tradução de Mário Laranjeira. São Paulo: Martins Fontes, 2004a.

- A preparação do romance. Volume I. Tradução de Leyla Perrone-Moises. São Paulo: Martins, 2005.

- A preparação do romance. Volume II. Tradução de Leyla Perrone-Moisés. São Paulo: Martins Fontes, 2005a.

. Sade, Fourier, Loyola. Tradução de Mário Laranjeira.

São Paulo: Martins Fontes, 2005b.

. Fragmentos de um discurso amoroso. Tradução de Márcia

Valéria Martinez de Aguiar. São Paulo: Martins Fontes, 2007.

. Aula. Tradução de Leyla Perrone-Moisés. São Paulo: Cultrix, 2007a.

- Mitologias. Tradução de Rita Buongermino, Pedro de

Souza e Rejane Janowitzer. Rio de Janeiro: DIFEL, 2007b.

. Crítica e Verdade. Tradução de Leyla Perrone-Moisés.

São Paulo: Perspectiva, 2007c.

- A câmara clara. Tradução de Júlio Castanõn

Guimarães. Rio de Janeiro: Nova Fronteira, 2012.

BENVENISTE, Émile. Problemas de linguística geral I. Tradução de Maria da Glória Novak e Maria Luisa Neri. Campinas-SP: Pontes Editores, 2005.

BLANCHOT, Maurice. O livro por vir. Tradução de Leyla Perrone-Moisés. São Paulo: Martins Fontes, 2005, p. 321. 
O espaço literário. Tradução de Álvaro Cabral. Rio de

Janeiro: Rocco, 2011.

DELEUZE, Gilles; GUATTARI, Félix. Mil platôs: capitalismo e esquizofrenia. Vol. 1. Tradução de Ana Lúcia de Oliveira. Rio de Janeiro: Ed. 34, 1995.

DERRIDA, Jacques. Margens da filosofia. Tradução de Joaquim Torres Costa e António M. Magalhães. Campinas-S.P.: Papirus, 1991.

A escritura e a diferença. Tradução de Maria Beatriz

Marques Nizza da Silva. São Paulo: Editora Perspectiva, 1995.

"As mortes de Roland Barthes". Revista Brasileira de

Sociologia da Emoção. Tradução de Mauro Guilherme Pinheiro

Koury. Agosto de 2008, volume VII, número 20, p. 264-336.

FOUCAULT, Michel. $A$ ordem do discurso. Tradução de Laura

Fraga de Almeida. São Paulo: Loyola, 1998. A arqueologia do saber. Tradução de Luiz Felipe Baeta

Neves. Rio de Janeiro: Forense Universitária, 2005.

. "Prefácio à transgressão". In: Ditos e Escritos

III. Estética: Literatura e Pintura, Música e Cinema. Tradução de Inês Autran Dourado Barbosa. Rio de janeiro: Forense Universitária, 2009.

LACAN, Jacques. O Seminário. Livro 7: A ética da psicanálise. Tradução de Antônio Quinet. Rio de Janeiro: Jorge Zahar Editor, 1997.

MAN, Paul de. "Autobiografia como des-figuração". Sopro. No 71, maio de 2012. Disponível em: www.culturaebarbarie. org/sopro/outros/autobiografia.html\#.UhIo3Z-5djo. Acesso em: 19/08/2013.

MARTY, Éric. Roland Barthes: o ofício de escrever. Tradução de Daniela Cerdeira. Rio de Janeiro: DIFEL, 2009.

NASCIMENTO, Evando. "Retrato do autor como leitor". Disponível em: http://www.evandonascimento.net.br/ ensaios/retrato_do_autor_como_leitor.pdf. Acesso em: 07/07/2014.

PERRONE-MOISÉS, Leyla. "Lição de casa" (prefácio). In: BARTHES, Roland. Aula. Tradução de Leyla Perrone-Moisés. São Paulo: Cultrix, 2007a.

PINO, Claudia Amigo. Roland Barthes: a aventura do romance. Rio de Janeiro: 7 letras, 2015. 
